\title{
Social Transfers and Child Poverty in European Countries: Pro-poor Targeting or Pro-child Targeting?
}

\author{
ELENA BÁRCENA-MARTÍN*, M. CARMEN BLANCO-ARANA** AND \\ SALVADOR PÉREZ-MORENO***
}

*Department of Applied Economics (Statistics and Econometrics), University of Malaga, Malaga, E-29071, Spain

email: barcenae@uma.es

** Department of Applied Economics (Public Finance, Economic Policy and Political Economy), University of Malaga, Malaga, E-29071, Spain

email: c.blancoarana@uma.es

${ }^{* * *}$ Department of Applied Economics (Public Finance, Economic Policy and Political

Economy), University of Malaga, Malaga, E-29071, Spain

email: sperezmoreno@uma.es

\begin{abstract}
Children are generally at a higher risk of poverty than the population as a whole, although the mechanisms that lead to their socio-economic vulnerability vary widely across European countries. This paper aims to further our understanding of to what extent cross-country variations in child poverty risk are associated with different ways of social transfer targeting: pro-poor versus pro-child targeting. In particular, we address the potential impact on child poverty of countries' intent to target transfers at lower incomes and children across 30 European countries. Using a multilevel framework, we find that not only the size of the transfer system, but also the form of targeting matters in reducing child poverty. Specifically, the countries' intent to target children matters even more than their intent to target lower incomes, in terms of reducing child poverty. Moreover, the prevalence of multi-generational households in a country seems to be associated with an attempt to protect against child poverty in countries with lower levels of pro-child targeting.
\end{abstract}

\section{Introduction}

Child poverty has become one of the most important topics requiring attention in Europe today. There is an imperative to reduce child poverty in order to reach the European Union (EU) headline poverty reduction target set out by the Europe 2020 strategy. It is well documented in the literature that, on average, around one out of every five children is living in poverty in the EU (Atkinson and Marlier, 2010; TÁRKI, 2011; among others). This highlights the paradoxical reality of child poverty in the developed world, which has been aggravated in recent years by a growing income inequality. 
Overall, the extent to which children's characteristics (e.g. the type of family in which they live, the parents' education, the labour status of the head of the household, etc) manifest themselves in high poverty rates mainly depends on the household and institutional settings in which those characteristics are present. Previous analyses have most often focused on the macro relationships between institutions and outcomes, underlining the crucial role of social policy transfers in the alleviation of child poverty (Kangas and Palme, 2000; Matsaganis et al., 2006; TÁRKI, 2010; Diris et al., 2017). However, there are good grounds for expecting an improvement in our understanding by bringing together countrylevel factors and micro-level characteristics of children in the analysis of child poverty because the redistributive outcomes of a particular system are dependent on the characteristics of the underlying population (Salanauskaite and Verbist, 2013; Marx et al., 2016; Diris et al., 2017).

One of the institutional mechanisms through which public policies may influence child poverty is social expenditure consisting of direct transfers to households, which act by increasing household income and thus reducing the intergenerational transmission of poverty. From a rationale perspective, it works as a redistribution device or as insurance against unexpected income loss (e.g. Corak, 2006). The most accepted finding is that social transfer income packages, as a whole, play an important role in preventing poverty. Even though the size of social transfer spending is recognised in the literature as a key factor in reducing child poverty (see, e.g. Chzhen, 2016; Diris et al., 2017), the impact of different policy intentions has not been well assessed (Salanauskaite and Verbist, 2013), especially the effectiveness of alternative targeting mechanisms. In line with Devereux et al. (2017), given the inevitability of trade-offs, there is no 'best' mechanism for social transfer targeting and, ultimately, it is a matter not only of policy intention but of empirical debate in each particular context.

The purpose of this article is to gauge the potential impact on child poverty of the countries' intent to target lower incomes and children, in order to shed light on which kind of targeting is more effective in reducing child poverty: pro-poor or pro-child targeting. To this end, beyond the size of social transfers, we consider two input indicators: pro-poor targeting (the ratio of expenditure on meanstested transfers over expenditure on total transfers) and pro-child targeting (the share of social protection expenditure specifically targeted at family/children). While pro-poor targeting is related to a vertical equity objective - 'unequal treatment of unequals' - pro-child targeting refers to a horizontal equity objective - 'equal treatment of equals' - (Verbist and Van Lancker, 2016).

To facilitate an approach that integrates individual and contextual dimensions, we take advantage of multilevel techniques. We use the European Union Statistics on Income and Living Conditions (EU-SILC) data set for the 2012 wave, as well as some significant contextual variables from Eurostat for 30 European countries. The novelty of our contribution is that we specifically 
examine whether pro-poor targeting or pro-child targeting matters most in reducing child poverty risk in varied policy environments. We do this by controlling for socio-economic characteristics of children, country-level indicators on labour market performance and countries' living standards. The results reveal the importance of the interaction of policy intent with country-specific demographic conditions, particularly the prevalence of multigenerational households.

The remainder of the paper is as follows. The next section summarises the main findings in the literature and states some hypotheses. The data and explanatory variables are then described. Subsequently, the methodology is presented and the results are discussed. Finally, some conclusions are drawn.

\section{Background and hypotheses}

Previous literature shows that poverty risk in general, and child poverty risk in particular, is shaped by the demographic and socio-economic characteristics of household members. It is very well documented that children are significantly more likely to be poor when they live with only one parent (Social Protection Committee, 2008; Atkinson and Marlier, 2010; Chzhen and Bradshaw, 2012; Skinner et al., 2017), and also that the proportion of children in households where nobody works is strongly correlated with child poverty rates (Whiteford and Adema, 2007; Chen and Corak, 2008; TÁRKI, 2010). Multi-generational living arrangements have been shown to be a way to provide a safety net for some and especially for children (Duflo, 2000; Hamoudi and Thomas, 2005).

Some studies also report that child outcomes differ greatly at different stages of childhood reflecting different developmental stages and childcare arrangements (TÁRKI, 2011). Moreover, child well-being is directly affected by the type and quality of the dwelling where the child lives and child poverty risk is greater for children living in rented and subsidised housing than for those whose parents are homeowners (Burrows, 2003; TÁRKI, 2011). Eurostat (2013) indicates that the risk of poverty is higher in thinly populated areas of the EU than in densely or moderately populated areas, suggesting a strong location effect in the risk of poverty.

Moreover, it is commonly accepted that child poverty risk is significantly shaped by the demographic and socio-economic characteristics of parents. Several authors point out that certain households' age composition can place a child at a higher risk of poverty. (Chen and Corak, 2008; Brady et al., 2009; Chzhen and Bradshaw, 2012). Other studies indicate the importance of parents' education, concluding that children that live with parents with a lower level of education are more likely to be poor than those whose parents have a higher level, since household income is influenced by the educational level of its members (Chzhen and Bradshaw, 2012; Gornick and Jäntti, 2012). In turn, 
parents' labour market participation is a fundamental determinant of child poverty given that employment-generated income is the most important source of the household budget (Ferrarini, 2006; Chen and Corak, 2008; Gornick and Jäntti, 2012).

According to Strelitz and Lister (2008) and Atkinson and Marlier (2010), there is a significant relationship between poverty and poor health/disability because households with members in poor health or with a disability face extra costs. There is also evidence of a greater risk of poverty among children whose parents are immigrants, especially if the parents were born outside the EU (TÁRKI, 2010).

As regards country-level aspects, researchers point out the importance of social policy, particularly financial assistance aimed at reducing the risk of child poverty (Misra et al., 2007; Scott, 2008; Bäckman, 2009; Bäckman and Ferrarini, 2010; Chzhen and Bradshaw, 2012; among others). In this sense, there is ample evidence that greater publicly funded support for families is significantly correlated to lower child poverty rates in countries where such policies are implemented (Bradshaw and Finch, 2003; Ferrarini, 2006; Notten and Gassman, 2008; Engster, 2012).

Unlike the consensus on the importance of the size of social transfers, the debate on the effectiveness of targeted policies to reduce child poverty remains open. Targeting can be concerned with how the budget is meant to be distributed (targeting intentions) or how it is actually distributed between beneficiaries (targeting outcomes). Let us recall that we are concerned with the targeting intentions, not with the outcomes. In this paper, targeting intentions are captured by two previously-defined indicators: pro-poor targeting and pro-child targeting.

On the one hand, proponents of targeting benefits at the poor argue that it entails a more efficient use of resources because social spending goes to those who really need it and hence has a large effect on poverty reduction (Besley, 1990). In fact, means-testing is a way to achieve targeting that has the function of allocating welfare to persons or households on the basis of their financial resources, with a considerable potential impact in terms of poverty alleviation. However, propoor targeting comes at a cost. Means-tested schemes inherently have a number of problems, such as significant administrative costs, lower rates of take-up and labour market and savings disincentives, which reduce their effectiveness in combating poverty (Atkinson, 1998; Notten and Gassmann, 2008; Bradshaw, 2012; Van Lancker and Van Mechelen, 2015).

On the other hand, there are other ways of targeting, including allocating benefits on the basis of age, physical status, marital status, etc., which selects individuals belonging to an easily-identifiable 'group' or 'category' (Van Oorschot, 2002). In this way, pro-child targeting, as a type of categorical targeting focused on children, constitutes an alternative targeting for reducing child poverty that avoids the inherent problems of means-tested schemes. The distributive impact of pro-child targeting partly depends on the socio-demographic structure 
of society because children are not randomly distributed over the population and, for instance, they can be over-represented in low-income households. This is, for European countries, in line with Verbist and Van Lancker (2016), who argue that horizontal equity and vertical equity are inherently interrelated.

In this paper we address the potential impact on child poverty of the countries' intent to target children and lower incomes from a comparative perspective. Our expectations read as follows:

(H1) Current literature usually points to the size of the transfer system as the primary determinant of child poverty. We test this feature of the transfer system as a determinant in the fight against child poverty.

(H2) We check the effect of the method of targeting on reducing child poverty. We first test whether it can be shown that the more benefits a country targets at lower incomes, the lower the risk of child poverty.

(H3) In the same way, we check whether it can be shown that the higher the level of spending distributed amongst children and families in a country, the lower the risk of child poverty.

(H4) Transfers targeted towards low income positions should be effective in reducing child poverty. Nonetheless, as the effect of the type of targeting can be highly dependent on the position of children in the income distribution (Diris et al., 2017), we question the most effective targeting tool for poverty reduction. We expect that both methods of targeting are effective, but targeting children could be even more effective than targeting lower incomes. These hypotheses are formulated taking into account the location of children in the income distribution.

Using EU-SILC 2012 data, we confirm that children are over-represented in the lowest deciles of the distribution (Table A2.1 of Supplementary material). Specifically, we find that their relative income position is closely related to child poverty, which automatically implies that policies affecting this position may also affect child poverty. Additionally, the composition of low-income deciles can affect the effect of pro-poor targeting in reducing child poverty. With EUSILC 2012 data, we show that lower income deciles are, to a large extent, composed of households without children (Table A2.2 of online Supplementary material). Consequently, contrary to the expected finding that transfers targeted at the poor must be more effective in reducing child poverty, we find that pro-child targeting is more effective than pro-poor targeting given the socio-demographic structure of European countries.

(H5) The structure of the household is an important driver of the structure of social spending (Diris et al., 2017). In our data, we observe a negative association between pro-child targeting and the percentage of multigenerational households - households in which children cohabit with 
at least one person aged between 18 and 64 and at least one person aged 65 or above - which is especially significant in countries with more multigenerational households (negative correlation, -0.41). We test the reducing effect on child poverty of the prevalence of multi-generational households and check for its interaction with the targeting effects.

\section{Data and variables}

\section{Data}

In this paper we use the 2012 wave of the EU-SILC data set for 30 European countries (EU-28 plus Iceland and Norway). Contextual data stem from statistics collected by Eurostat for the countries involved in the analysis.

Our analysis is confined to children, defined as those under 18 years old living in the household unit (Chzhen and Bradshaw, 2012; Gornick and Jäntti, 2012; among others). The analysis pools the data from the 30 countries into one merged file that contains 66,882 households with 113,181 children. ${ }^{1}$ Following Eurostat, our poverty measure is based on annual disposable household income. ${ }^{2}$ To adjust for household size we use the modified Organisation for Economic Cooperation and Development (OECD) equivalence scale. ${ }^{3} \mathrm{~A}$ child is classified as poor if he/she lives in a household with disposable household equivalent income below 60 per cent of the contemporary median equivalent income of the country where the household is located.

Figure 1 displays child poverty rates for the 30 countries. We observe a significant variation in child poverty rates across countries in 2012, ranging from 8.20 per cent to 33.88 per cent. Romania, Bulgaria and Spain display the highest child poverty rates, while the lowest ones are found in Norway, Iceland and Denmark.

We observe that most of the countries display a higher poverty rate for children than the overall population, with the remarkable exceptions of Denmark, Finland and Norway. In general, there is a significant positive correlation between child poverty rates and overall poverty rates. We also find that countries with higher child poverty rates tend to present a large gap between child and overall poverty rates.

\section{Explanatory variables}

As all children in the same household share the same particular characteristics of the household, we use data from households - stored in the household file combined with data on the characteristics of fathers and mothers of children, which are recorded in the individual file.

We consider the following explanatory variables related to the household as a whole. The descriptive statistics can be found in Table A2.3 and Table A2.4 of the online Supplementary material. The binary variables lone-parent, multi- 


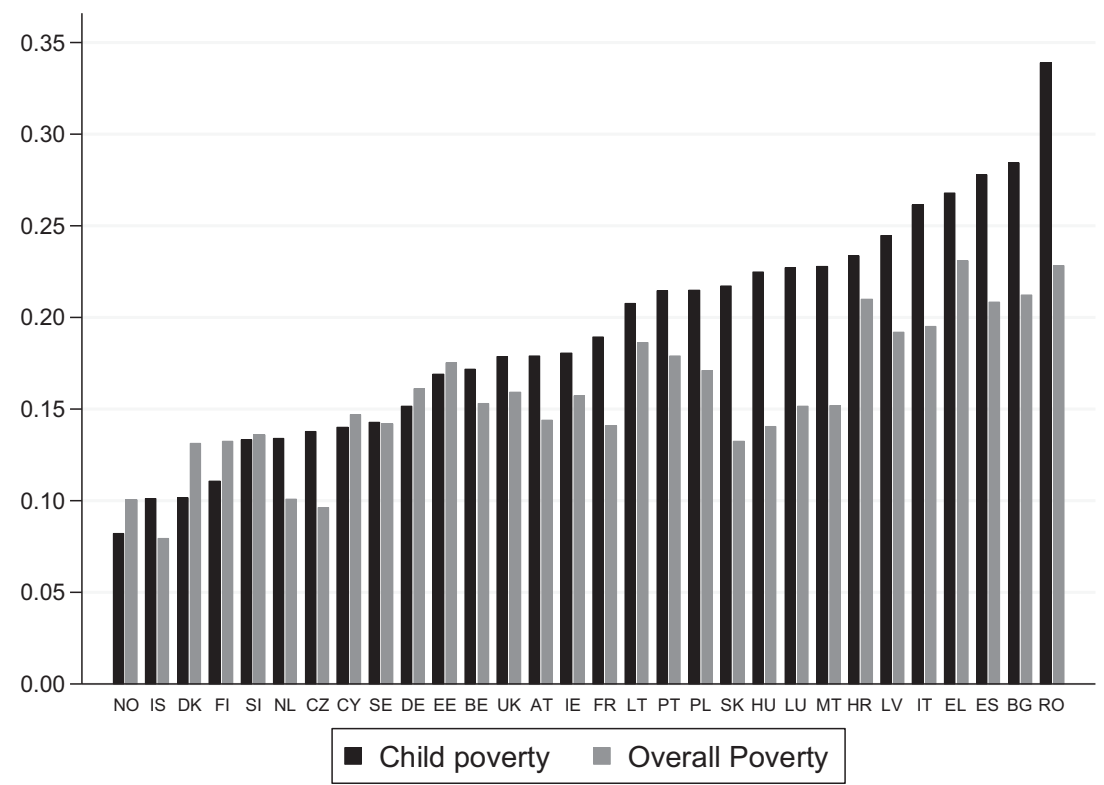

Figure 1. Child poverty rates

Source: EU-SILC (cross-sectional version 2012-3). Sorted by child poverty rate.

Note: AT: Austria; BE: Belgium; BG: Bulgaria; CY: Cyprus; CZ: Czech Republic; DE: Germany; DK: Denmark; EE: Estonia; EL: Greece; ES: Spain; FI: Finland; FR: France; HR: Croatia; HU: Hungary; IE: Ireland; IS: Iceland; IT: Italy; LT: Lithuania; LU: Luxembourg; LV: Latvia; MT: Malta; NL: The Netherlands; NO: Norway; PL: Poland; PT: Portugal; RO: Romania; SE: Sweden; SI: Slovenia; SK: Slovakia; UK: United Kingdom.

generational and jobless reflect: lone parenthood, households in which at least three generations live, and households where no one works, respectively. We also take into account the number of children aged within several ranges: Nch_2, Nch_3_5, Nch_6_11 and Nch_12_17. We include the variable owner that takes the value of 1 if the outright owner of the dwelling is a member of the household. Finally, we consider the variable thinly populated, which takes the value of o if clusters of contiguous grid cells of $1 \mathrm{~km}^{2}$ have a density of at least 300 inhabitants per $\mathrm{km}^{2}$ and a minimum population of 5,000 and 1 otherwise.

Besides household variables, researchers suggest that certain characteristics of fathers and mothers are very relevant in explaining child poverty rates. We classify children as living with a young father/mother (younger than 30) and as living with an old father/mother (older than 65). Secondly, we consider the variable secondary father/mother and tertiary father/mother to capture the effect of education on child poverty. Thirdly, parents' labour market participation is considered through the binary variable father/mother working full time. We also incorporate the binary variable health father/mother, which indicates if their 
general health status is bad or very bad. Finally, we categorise children as living with EU immigrant father/mother and non-EU immigrant father/mother.

Our aim is to analyse the potential impact on child poverty of different features of social transfers. We present a set of contextual variables related to social transfers, as well as the labour market and the countries' standard of living, whose influence can be significant in child poverty rates according to the literature. All these variables introduced in the model are for 2011, which is the reference period for the household income for all countries except for the UK and Ireland. In the latter two countries, the variables refer to 2012 (here the income reference period refers to the period around the interview, with total income converted: to annual equivalents and to 12 months prior to the interview, respectively).

Note that, to examine the role of transfers in reducing poverty among children, we consider expenditure on all transfers as a way of measuring the size of the social transfer system. ${ }^{4}$ We include a variable, size, which is defined as cash spending on social protection as a percentage of gross domestic product (GDP). It is worth stressing that, in all countries except Greece, Spain and Poland, more than 60 per cent of families with children receive social transfers. These numbers are smaller if we refer to the proportion of overall families that receive transfers, although the same three countries have the smallest values. In all countries, child poverty rates would be higher if there were no transfers (Figure 2), although this analysis disregards any behavioural consequences of withdrawing them.

The assessment of the potential impact on child poverty of the countries' intent to target children and lower incomes is made through two input indicators ${ }^{5}$ : pro-poor targeting, defined as the ratio of expenditure on means-tested transfers over expenditure on total transfers multiplied by 100; and pro-child targeting, defined as the share of social protection expenditure specifically targeted at family/children, that is, the ratio of expenditure on family/children transfers ${ }^{6}$ over expenditure on total transfers multiplied by 100.

We also control for differences in the economic affluence of countries by introducing the variable GDP, which is the GDP per capita expressed in purchasing power standard as a percentage of the EU-28 average. This variable allows us to control for the effect of country-level living standards on child poverty risk and to test the robustness of our results in terms of social policy.

Other factors having a potentially significant effect on child poverty, and closely related to social transfer systems, are those referring to labour market performance (Brady, 2006; Whiteford and Adema, 2007; Chen and Corak, 2008; Bäckman, 2009). Given that parental unemployment is one of the main determinants of child poverty, higher unemployment rates within countries are also likely to contribute to higher child poverty rates. The variable employment is calculated by dividing the number of employed persons aged 20 to 64 by the total population of the same age group and multiplying by 100. 


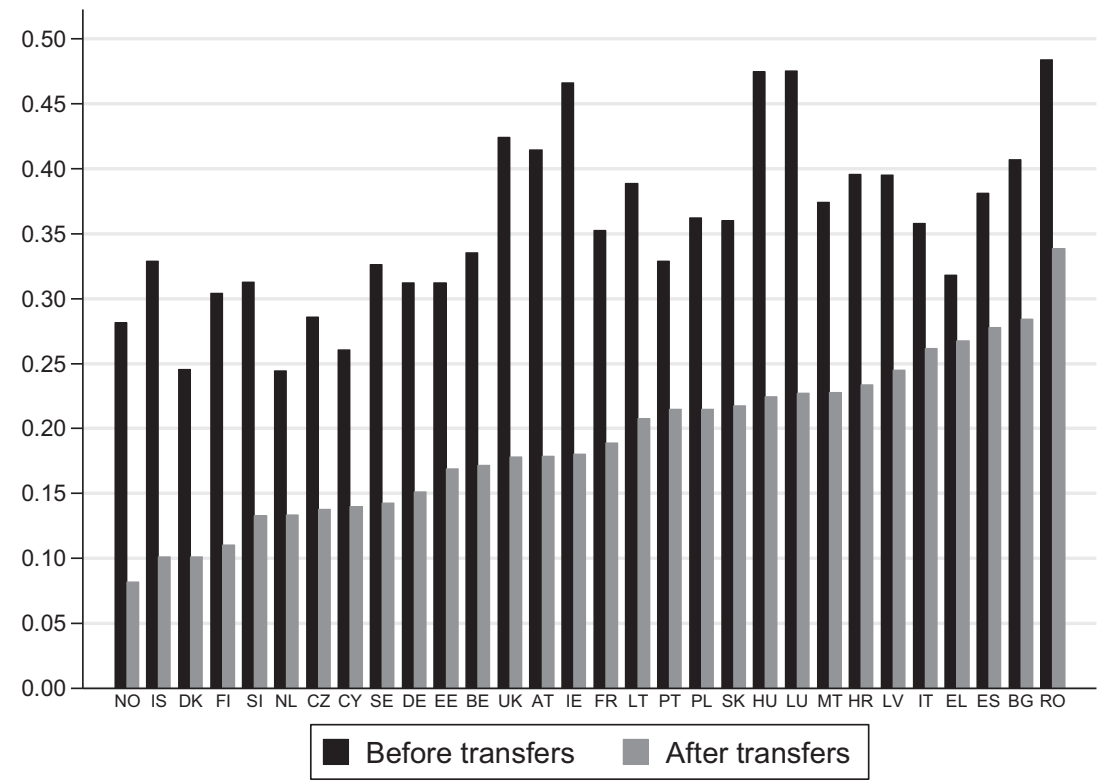

Figure 2. Child poverty rates before and after transfers

Source: EU-SILC (cross-sectional version 2012-3). Sorted by child poverty rate after transfers

However, the risk of poverty is conditioned more by work intensity and continuity in work than by having a job in itself. That is why, at country level, we take into account not only the employment rate, but also the percentage of individuals who are classified as employed and are poor (in-work poverty). In line with Marx et al. (2012), we expect that children living in a country with a high rate of working poor, once we control for the employment status at the household level, tend to have higher child poverty risk.

Regarding the family structure, Diris et al. (2017) state that it is an important driver of the structure of social spending and suggest that the higher the presence of multi-generational households in a country - that is, households in which at least three generations live - the lower the risk of child poverty. In our case, we assess the extent to which the prevalence of multi-generational households in a country (\% multi-generational households) affects child poverty directly and, indirectly, modulates the effect of pro-poor and pro-child targeting on child poverty.

\section{Methodology}

In line with our aim, we need to account for the hierarchical structure of our data involving two levels: children (level 1) nested into countries (level 2). Following the idea that children may be influenced by their social and political context, we 
might expect that two randomly selected children from the same country will tend to be more highly correlated than two children selected from different countries, and it is important to account for such unobserved country-level effects.

Conventional multivariate regression techniques cannot be employed with hierarchical data since the standard errors of variables at higher levels will be underestimated given that the degrees of freedom are calculated as if they were at the first level. As country differences are of substantive interest in this paper, we need a model in which we can explore information beyond clustering. Thus, multilevel models are the appropriate alternative.

One of the main advantages when we use mixed or multilevel models is that we gain precision compared to using aggregate (country-level) data only. We use a random intercept model $^{7}$ in which the intercept is allowed to vary between countries. ${ }^{8}$ We consider a latent continuous response, $y_{i c}^{*}$, representing the propensity for child $i$ in country $c$ to be poor as compared to not poor such that:

$$
y_{i c}=\left\{\begin{array}{l}
1 \text { if } y_{i c}^{*}>0 \\
0 \text { otherwise }
\end{array}\right.
$$

Let $x_{i c}$ be a covariate. A linear regression model is specified for the latent response $y_{i c}^{*}$

$$
y_{i c}^{*}=\beta_{o}+\beta_{1} x_{i c}+\xi_{c}+\varepsilon_{i c}
$$

where $\xi_{c}$ is the random intercept which represents the difference between the mean of child poverty risk in a given country $c$ and the overall mean, and $\varepsilon_{i c}$ are the individual level residuals: that is, the difference between the child poverty risk of individual $i$ and the averaged child poverty risk in his/her country $c$. We can identify the variance of child poverty risk between countries, $\sigma_{\xi}^{2}$, and the variance of child poverty risk between individuals within countries, $\sigma_{\varepsilon}^{2}$. The residuals $\varepsilon_{i c}$ are distributed as a logistic distribution with mean $o$ and variance $\pi^{2} / 3$ and are independent of $\xi_{c}$, which follows a normal distribution with zero mean. The variance partition coefficient (VPC) is defined as the ratio of the variance of child poverty risk between individuals within countries to total variance.

We first estimate Model A that includes household-level variables to test if international differences in the contribution of demographic and socio-economic factors, that place children in families with different poverty risks, may have an effect on the variability of child poverty risk between countries. We then add the three indicators regarding social transfers (Model B) to check how much of the unexplained variation is due to differences in the size and targeting levels of the social transfer systems. Model C adds the GDP per capita in the previous model to control for living standard effects. Model D controls for the labour market effect in order to test if the effect of social transfer remains after controlling for 
labour market differences and the country's mean income. Finally, the effect of multi-generational households and the possible differential effect of targeting depending on the presence of this type of household in a country is analysed in Model E.

\section{Results}

The results of the estimations for the five logistic multilevel models ${ }^{9}$ with the random intercept are shown in Table 1.

The effects of household characteristics are very similar across the five estimated models. Our results are in line with the literature: a child living with only one parent is 20 per cent more likely to be poor than one living with two parents. Children living in multi-generational households are 41 per cent less likely to be poor than those living in single-unit households; therefore, this type of family can be viewed as a safety net for children. We confirm that children in households where no one works have more than three and a half times higher odds of being poor than those living in households where at least one person is working. The odds of being poor increase by around 30 per cent with each additional child and even more if the child is between 12 and 17 years old. A child's odds of being poor are lower if he/she is living in a household that does not have to pay for the dwelling. As Eurostat (2013), we find significant evidence that thinly populated areas in European countries are at a higher risk of poverty.

Regarding parents' characteristics, our results are aligned with previous results. We find that children living with a younger parent, a less-educated parent or an unemployed parent are more likely to be poor. Contrary to our expectations, the variable health father/mother does not entail a significantly higher risk of child poverty. ${ }^{10}$ Finally, children with an EU immigrant father/mother are more likely to be poor and even more so in the case of those living with a non-EU immigrant father/mother.

As our objective is to further our understanding of to what extent different features of the social transfer systems can affect child poverty risk and crosscountry variations in child poverty, we introduce the three aforementioned indicators of social transfers (size, pro-child_targeting and pro-poor_targeting) in Model B. The results show that there is a statistically significant relationship between the indicators of social transfers and the child's likelihood of being poor. The higher the size and targeting, either pro-child ${ }^{11}$ or pro-poor targeting, the lower the risk of child poverty; with pro-child targeting having a higher impact on child poverty risk. ${ }^{12}$ Therefore, we find evidence to accept the first four hypotheses.

We can argue that child-oriented transfers reduce child poverty because children are not randomly distributed over the population but mostly in lower 
Table 1. Odds ratio of child poverty (2012)

\begin{tabular}{|c|c|c|c|c|c|}
\hline & Model A & Model B & Model C & Model D & Model E \\
\hline \multicolumn{6}{|l|}{ Micro-variables } \\
\hline lone-parent & $\begin{array}{c}1.200^{*} \\
{[0.125]}\end{array}$ & $\begin{array}{c}1.203^{*} \\
{[0.125]}\end{array}$ & $\begin{array}{c}1.201^{*} \\
{[0.125]}\end{array}$ & $\begin{array}{c}1.213^{*} \\
{[0.128]}\end{array}$ & $\begin{array}{c}1.205^{*} \\
{[0.125]}\end{array}$ \\
\hline multiunit & $\begin{array}{l}0.589^{* * *} \\
{[0.074]}\end{array}$ & $\begin{array}{c}0.587^{* * *} \\
{[0.074]}\end{array}$ & $\begin{array}{l}0.586^{* * *} \\
{[0.074]}\end{array}$ & $\begin{array}{l}0.589^{* * *} \\
{[0.075]}\end{array}$ & $\begin{array}{c}0.583^{* * *} \\
{[0.073]}\end{array}$ \\
\hline jobless & $\begin{array}{l}3.730^{* * *} \\
{[0.460]}\end{array}$ & $\begin{array}{l}3.719^{* * *} \\
{[0.457]}\end{array}$ & $\begin{array}{l}3.714^{* * *} \\
{[0.457]}\end{array}$ & $\begin{array}{l}3.700^{* * *} \\
{[0.459]}\end{array}$ & $\begin{array}{l}3.710^{* * *} \\
{[0.456]}\end{array}$ \\
\hline Nch_2 & $\begin{array}{c}1.287^{* * *} \\
{[0.102]}\end{array}$ & $\begin{array}{c}1.284^{* * *} \\
{[0.102]}\end{array}$ & $\begin{array}{c}1.283^{* * *} \\
{[0.102]}\end{array}$ & $\begin{array}{l}1.286^{* * *} \\
{[0.102]}\end{array}$ & $\begin{array}{c}1.284^{* * *} \\
{[0.102]}\end{array}$ \\
\hline Nch_3_5 & $\begin{array}{l}1.334^{* * *} \\
{[0.078]}\end{array}$ & $\begin{array}{c}1.333^{* * *} \\
{[0.078]}\end{array}$ & $\begin{array}{l}1.332^{* * *} \\
{[0.078]}\end{array}$ & $\begin{array}{c}1.333^{* * *} \\
{[0.078]}\end{array}$ & $\begin{array}{l}1.332^{* * *} \\
{[0.078]}\end{array}$ \\
\hline Nch_6_11 & $\begin{array}{l}1.310^{* * *} \\
{[0.054]}\end{array}$ & $\begin{array}{c}1.310^{* * *} \\
{[0.054]}\end{array}$ & $\begin{array}{l}1.309^{* * *} \\
{[0.054]}\end{array}$ & $\begin{array}{l}1.310^{* * * *} \\
{[0.054]}\end{array}$ & $\begin{array}{c}1.309^{* * *} \\
{[0.054]}\end{array}$ \\
\hline Nch_12_17 & $\begin{array}{c}1.560^{* * *} \\
{[0.050]}\end{array}$ & $\begin{array}{c}1.561^{* * *} \\
{[0.050]}\end{array}$ & $\begin{array}{c}1.561^{* * *} \\
{[0.050]}\end{array}$ & $\begin{array}{c}1.56 \mathrm{o}^{* * *} \\
{[0.050]}\end{array}$ & $\begin{array}{c}1.559^{* * *} \\
{[0.050]}\end{array}$ \\
\hline owner & $\begin{array}{c}0.992 \\
{[0.051]}\end{array}$ & $\begin{array}{c}0.981 \\
{[0.050]}\end{array}$ & $\begin{array}{c}0.978 \\
{[0.050]}\end{array}$ & $\begin{array}{c}0.975 \\
{[0.049]}\end{array}$ & $\begin{array}{c}0.977 \\
{[0.050]}\end{array}$ \\
\hline thinly populated & $\begin{array}{l}1.423^{* * * *} \\
{[0.111]}\end{array}$ & $\begin{array}{c}1.426^{* * *} \\
{[0.108]}\end{array}$ & $\begin{array}{l}1.423^{* * *} \\
{[0.108]}\end{array}$ & $\begin{array}{c}1.421^{* * *} \\
{[0.106]}\end{array}$ & $\begin{array}{c}1.429^{* * *} \\
{[0.109]}\end{array}$ \\
\hline young father & $\begin{array}{c}1.203^{*} \\
{[0.120]}\end{array}$ & $\begin{array}{c}1.202^{*} \\
{[0.120]}\end{array}$ & $\begin{array}{r}1.199^{*} \\
{[0.120]}\end{array}$ & $\begin{array}{c}1.207^{*} \\
{[0.119]}\end{array}$ & $\begin{array}{c}1.203^{*} \\
{[0.120]}\end{array}$ \\
\hline old father & $\begin{array}{c}0.421^{* * *} \\
{[0.073]}\end{array}$ & $\begin{array}{c}0.421^{* * *} \\
{[0.072]}\end{array}$ & $\begin{array}{l}0.421^{* * *} \\
{[0.072]}\end{array}$ & $\begin{array}{l}0.419^{* * *} \\
{[0.072]}\end{array}$ & $\begin{array}{l}0.422^{* * *} \\
{[0.072]}\end{array}$ \\
\hline secondary father & $\begin{array}{c}0.842^{* *} \\
{[0.068]}\end{array}$ & $\begin{array}{c}0.841^{* *} \\
{[0.067]}\end{array}$ & $\begin{array}{c}0.839^{* *} \\
{[0.067]}\end{array}$ & $\begin{array}{c}0.846^{* *} \\
{[0.067]}\end{array}$ & $\begin{array}{c}0.840^{* *} \\
{[0.067]}\end{array}$ \\
\hline tertiary father & $\begin{array}{c}0.375^{* * *} \\
{[0.041]}\end{array}$ & $\begin{array}{c}0.376^{* * *} \\
{[0.041]}\end{array}$ & $\begin{array}{l}0.375^{* * *} \\
{[0.041]}\end{array}$ & $\begin{array}{l}0.378^{* * *} \\
{[0.041]}\end{array}$ & $\begin{array}{c}0.376^{* * *} \\
{[0.041]}\end{array}$ \\
\hline work father & $\begin{array}{l}0.277^{* * *} \\
{[0.016]}\end{array}$ & $\begin{array}{l}0.277^{* * *} \\
{[0.016]}\end{array}$ & $\begin{array}{c}0.278^{* * *} \\
{[0.016]}\end{array}$ & $\begin{array}{l}0.278^{* * *} \\
{[0.016]}\end{array}$ & $\begin{array}{l}0.278^{* * *} \\
{[0.016]}\end{array}$ \\
\hline health father & $\begin{array}{c}0.933 \\
{[0.113]}\end{array}$ & $\begin{array}{c}0.932 \\
{[0.113]}\end{array}$ & $\begin{array}{c}0.932 \\
{[0.113]}\end{array}$ & $\begin{array}{c}0.931 \\
{[0.112]}\end{array}$ & $\begin{array}{c}0.931 \\
{[0.112]}\end{array}$ \\
\hline EU immigrant father & $\begin{array}{c}1.626^{* *} \\
{[0.347]}\end{array}$ & $\begin{array}{c}1.638^{* *} \\
{[0.347]}\end{array}$ & $\begin{array}{l}1.656^{* *} \\
{[0.353]}\end{array}$ & $\begin{array}{c}1.613^{* *} \\
{[0.346]}\end{array}$ & $\begin{array}{c}1.640^{* *} \\
{[0.347]}\end{array}$ \\
\hline non-EU immigrant father & $\begin{array}{c}2.177^{* * *} \\
{[0.244]}\end{array}$ & $\begin{array}{c}2.183^{* * *} \\
{[0.247]}\end{array}$ & $\begin{array}{c}2.187^{* * *} \\
{[0.248]}\end{array}$ & $\begin{array}{c}2.172^{* * *} \\
{[0.244]}\end{array}$ & $\begin{array}{c}2.181^{* * *} \\
{[0.245]}\end{array}$ \\
\hline young mother & $\begin{array}{l}1.627^{* * *} \\
{[0.122]}\end{array}$ & $\begin{array}{c}1.623^{* * *} \\
{[0.121]}\end{array}$ & $\begin{array}{l}1.622^{* * *} \\
{[0.121]}\end{array}$ & $\begin{array}{l}1.620^{* * *} \\
{[0.121]}\end{array}$ & $\begin{array}{l}1.621^{* * * *} \\
{[0.121]}\end{array}$ \\
\hline old mother & $\begin{array}{l}0.576^{* * *} \\
{[0.052]}\end{array}$ & $\begin{array}{c}0.575^{* * *} \\
{[0.052]}\end{array}$ & $\begin{array}{l}0.575^{* * *} \\
{[0.052]}\end{array}$ & $\begin{array}{c}0.573^{* * *} \\
{[0.052]}\end{array}$ & $\begin{array}{l}0.578^{* * *} \\
{[0.052]}\end{array}$ \\
\hline secondary mother & $\begin{array}{l}0.642^{* * * *} \\
{[0.064]}\end{array}$ & $\begin{array}{c}0.641^{* * *} \\
{[0.064]}\end{array}$ & $\begin{array}{c}0.639^{* * *} \\
{[0.064]}\end{array}$ & $\begin{array}{c}0.646^{* * *} \\
{[0.064]}\end{array}$ & $\begin{array}{c}0.641^{* * *} \\
{[0.063]}\end{array}$ \\
\hline tertiary mother & $\begin{array}{c}0.298^{* * *} \\
{[0.032]}\end{array}$ & $\begin{array}{c}0.297^{* * *} \\
{[0.032]}\end{array}$ & $\begin{array}{c}0.296^{* * *} \\
{[0.032]}\end{array}$ & $\begin{array}{c}0.301^{* * *} \\
{[0.032]}\end{array}$ & $\begin{array}{c}0.298^{* * *} \\
{[0.032]}\end{array}$ \\
\hline work mother & $\begin{array}{c}0.308^{* * *} \\
{[0.030]}\end{array}$ & $\begin{array}{l}0.306^{* * *} \\
{[0.030]}\end{array}$ & $\begin{array}{l}0.306^{* * *} \\
{[0.030]}\end{array}$ & $\begin{array}{l}0.308^{* * *} \\
{[0.030]}\end{array}$ & $\begin{array}{l}0.307^{* * *} \\
{[0.030]}\end{array}$ \\
\hline health mother & $\begin{array}{c}0.907 \\
{[0.088]}\end{array}$ & $\begin{array}{c}0.907 \\
{[0.088]}\end{array}$ & $\begin{array}{c}0.905 \\
{[0.088]}\end{array}$ & $\begin{array}{c}0.907 \\
{[0.088]}\end{array}$ & $\begin{array}{c}0.905 \\
{[0.088]}\end{array}$ \\
\hline EU immigrant mother & $\begin{array}{l}1.573^{* * *} \\
{[0.265]}\end{array}$ & $\begin{array}{l}1.578^{* * *} \\
{[0.268]}\end{array}$ & $\begin{array}{l}1.593^{* * *} \\
{[0.270]}\end{array}$ & $\begin{array}{l}1.549^{* * *} \\
{[0.257]}\end{array}$ & $\begin{array}{c}1.575^{* * *} \\
{[0.268]}\end{array}$ \\
\hline non-EU immigrant mother & $\begin{array}{l}1.78 \mathrm{o}^{* * *} \\
{[0.121]}\end{array}$ & $\begin{array}{l}1.78 \mathrm{o}^{* * *} \\
{[0.121]}\end{array}$ & $\begin{array}{l}1.786^{* * *} \\
{[0.122]}\end{array}$ & $\begin{array}{c}1.774^{* * *} \\
{[0.120]}\end{array}$ & $\begin{array}{c}1.779^{* * *} \\
{[0.121]}\end{array}$ \\
\hline
\end{tabular}


Table 1. Continued

\begin{tabular}{|c|c|c|c|c|c|}
\hline & Model A & Model B & Model C & Model D & Model E \\
\hline \multicolumn{6}{|l|}{ Macro-variables } \\
\hline size & & $\begin{array}{l}0.947^{* * *} \\
{[0.011]}\end{array}$ & $\begin{array}{l}0.961^{* * *} \\
{[0.013]}\end{array}$ & $\begin{array}{c}0.970^{* * *} \\
{[0.009]}\end{array}$ & $\begin{array}{c}0.974^{* *} \\
{[0.012]}\end{array}$ \\
\hline pro-child targeting & & $\begin{array}{c}0.938^{* * *} \\
{[0.017]}\end{array}$ & $\begin{array}{c}0.960^{*} \\
{[0.021]}\end{array}$ & $\begin{array}{c}0.970^{* *} \\
{[0.012]}\end{array}$ & $\begin{array}{c}0.905^{* *} \\
{[0.036]}\end{array}$ \\
\hline pro-poor targeting & & $\begin{array}{c}0.982^{* * *} \\
{[0.006]}\end{array}$ & $\begin{array}{c}0.980^{* * *} \\
{[0.006]}\end{array}$ & $\begin{array}{c}0.983^{* * *} \\
{[0.005]}\end{array}$ & $\begin{array}{c}0.983^{*} \\
{[0.010]}\end{array}$ \\
\hline GDP & & & $\begin{array}{c}0.997 \\
{[0.002]}\end{array}$ & & \\
\hline employment & & & & $\begin{array}{c}0.976^{* * *} \\
{[0.008]}\end{array}$ & \\
\hline in-work poverty & & & & $\begin{array}{l}1.056^{* * *} \\
{[0.012]}\end{array}$ & \\
\hline $\begin{array}{l}\% \text { multigenerational } \\
\text { households }\end{array}$ & & & & & $\begin{array}{c}0.862^{*} \\
{[0.075]}\end{array}$ \\
\hline $\begin{array}{l}\text { pro-child targeting * \% } \\
\text { multigenerational } \\
\text { households }\end{array}$ & & & & & $\begin{array}{l}1.021^{* *} \\
{[0.010]}\end{array}$ \\
\hline $\begin{array}{l}\text { pro-poor targeting * \% } \\
\text { multigenerational } \\
\text { households }\end{array}$ & & & & & $\begin{array}{c}1.005 \\
{[0.007]}\end{array}$ \\
\hline Constant & $0.385^{* * *}$ & $2.935^{* * *}$ & $2.325^{* *}$ & $4.238^{* *}$ & 1.735 \\
\hline Var in intercept & 0.228 & 0.080 & 0.072 & 0.034 & 0.054 \\
\hline VPC & 0.065 & 0.024 & 0.021 & 0.010 & 0.016 \\
\hline Observations & 66,882 & 66,882 & 66,882 & 66,882 & 66,882 \\
\hline Number of groups & 30 & 30 & 30 & 30 & 30 \\
\hline Log likelihood & $-10,516$ & $-10,501$ & $-10,500$ & $-10,490$ & $-10,496$ \\
\hline
\end{tabular}

Sources: EU-SILC (cross-sectional version; 2012-3), Eurostat (2011, accessed April 2017).

Standard deviations in brackets.

${ }^{* * *} \mathrm{p}<0.01,{ }^{* *} \mathrm{p}<0.05,{ }^{*} \mathrm{p}<0.1$

deciles, as shown in Table A2.1 of the online Supplementary material. Therefore, transfers targeted at children seem to increase children's incomes more than they increase the poverty threshold and eventually make them less vulnerable to poverty.

At the same time, pro-poor transfers reduce child poverty because children are placed in low-income deciles. However, the effect of such transfers on child poverty is smaller than in the case of pro-child transfers because these lower deciles are, to a larger extent, composed of households without children, as can be seen in Table A2.2 of the online Supplementary material. Therefore, pro-poor transfers are to a large extent distributed to households without children, thus increasing both the poverty threshold and the income for poor children, ultimately reducing child poverty less than pro-child targeting. 
In particular, the child's odds of being poor significantly decrease, by 6.2 per cent, for each 1-unit increase in pro-child targeting, while they decrease by only 1.2 per cent for each 1-unit increase in pro-poor targeting. Adding the social transfer indicators to the model reduces the percentage of the residual variation in the risk of child poverty due to country effects (VPC) from 6.5 to 2.4 per cent, which represents a 63.47 per cent reduction in relative terms. This implies that variations in the features of social transfers account for more than half of the unobserved country-level heterogeneity in child poverty outcomes, something that must be regarded as quite substantial.

In order to test the significance of social transfers, we control for GDP per capita in Model C. We find that size and pro-poor and pro-child targeting are still relevant aspects of social transfers regarding child poverty risk, as they remain statistically significant after controlling for contextual living standard effects. This corroborates the robustness of the results. We also observe that the GDP per capita of the country where the child is living is not statistically significant, which is consistent with the results of Chzhen and Bradshaw (2012).

Model D provides a demanding test by adding in the effect of the labour market to the risk of child poverty. Again, controlling for labour market effects does not alter our findings concerning social transfers. Our indicators of social transfers show, therefore, a high robustness in terms of their effects on the risk of child poverty. The results also indicate that both the employment rate and the in-work poverty rate have a statistically significant effect on the child's likelihood of being poor, with each variable going in the expected direction. The effect of the in-work poverty rate (child's odds of being poor significantly increase by 5.6 per cent for each 1-unit increase in the working poor rate) is higher than the effect of the employment rate (the odds of being poor significantly decrease by 2.4 per cent for each 1-unit increase). This shows that the level of integration in the labour market is important, but the quality of this integration as measured through the capacity to avoid poverty is also important. The findings of Marx et al. (2015) support this result as they argue that the determining labour market factor which causes a child to live in poverty is mainly based on the income received by their parents from the labour market - whether it is because their parents work part time or because they earn low wages - rather than on the situation of being employed or not.

Model E tests the possible influence of multi-generational households in a country over child poverty risk and over the effect of pro-poor and prochild targeting. We observe that the higher the proportion of multi-generational households in a country, the lower the chances of a child being poor. Moreover, as discussed previously, the lower the pro-child targeting, the higher the risk of child poverty, even though this relationship weakens in the presence of higher proportions of multi-generational households in a country. This corroborates the findings that the formation of multi-generational households seems to be 
associated with an attempt to protect against child poverty. Nonetheless, the pro-poor targeting effect on child poverty is not modulated by the prevalence of multi-generational households. These findings provide further evidence of how the socio-demographic compositions of countries (here the structure of the household) constitutes a key element to take into consideration when evaluating the effect of targeted policies, in line with Diris et al. (2017).

\section{Conclusion}

This study aims to improve our knowledge about the extent to which crosscountry variations in child poverty risk are associated with both pro-poor targeting and pro-child targeting. To do so, we use a multilevel framework in which we jointly take into consideration individual characteristics and countrylevel factors.

We find that, in general, the variation in child poverty is mainly due to country-level factors, particularly those related to social protection systems and, to a lesser degree, to individual characteristics. In particular, our findings highlight that the countries' intent to target children matters even more than their intent to target lower incomes in terms of reducing child poverty. In this sense, although targeting towards lower incomes is associated with lower child poverty levels, pro-child targeting reveals an even higher effectiveness, even after controlling for a country's living standards, labour market performance and the structure of the households. Thus, it should be stressed that, apart from the traditional justification of compensating for the costs associated with childrearing and minimising the welfare loss relative to childless families, pro-child targeting plays a significant role in reducing poverty in European countries, considering that horizontal equity and vertical equity are inherently interrelated. This is consistent with Verbist and Van Lancker (2016), who find that European countries that succeed in compensating for a high share of the costs of childrearing for all families largely tend to succeed in reducing the poverty gap as well. We argue that the reason why transfers targeted at children reduce child poverty more than transfers targeted at low incomes is related to the fact that children are largely located in the lower part of the income distribution and, at the same time, in the lower deciles there is a significant prevalence of childless families that are potential beneficiaries of pro-poor targeting.

All this reveals the importance of considering the socio-demographic environment when assessing ways of targeting as there is no 'best' mechanism for social transfer targeting and it is crucial to take into account how methods of targeting interact with country-specific demographic conditions. In this paper, when testing the possible influence of the prevalence of multi-generational households in a country, we find that, beyond the total spending and both propoor and pro-child targeting, the way in which pro-child targeting interacts with 
the prevalence of multi-generational households also matters for child poverty. In particular, lower pro-child targeting transfer systems are associated with a higher risk of poverty, but this effect is smaller in the presence of multi-generational households, thus confirming that the structure of households is an important driver of the structure of social spending.

Once we control for individual characteristics and country-level factors, a detailed analysis of countries reveals that the Netherlands, the Czech Republic and Norway are countries with a lower risk of child poverty. We find diverse social transfer systems in these countries, so there are no significant common features that could be regarded as examples of good practice. While Norway's and the Netherlands' expenditure in social transfer with respect to GDP is higher than the EU average, the Czech Republic shows a lower level of expenditure than the mean. The European System of Integrated Social Protection Statistics (ESSPROS) distinguishes four types of periodic cash benefits: (1) income maintenance benefit in the event of childbirth, (2) parental leave benefit, (3) family or child allowance and (4) other cash benefits. Family or child allowances are by far the most important type in the Netherlands and very important in the Czech Republic together with parental leave benefit, while for Norway it is the income maintenance benefit in the event of childbirth.

Regarding means-tested transfers, although they may be granted under all functions, they are particularly common in the housing and social exclusion functions for the Czech Republic and the Netherlands and in the function of oldage and survivors benefits for Norway. Moreover, most means-tested benefits are targeted at low-income households, but some may be directed at wider sections of the population. For example, certain schemes in the Netherlands provide means-tested housing and/or old age or social support benefits to households that cannot be regarded as suffering from extreme poverty.

To sum up, in line with Devereux et al. (2017) and Diris et al. (2017), we can claim that 'one-size-fits all' is not a good approach to social policymaking. Policy packages that are successful in one country may not be so in others. Success depends on policies being well aligned with their own socio-demographic settings (Salanauskaite and Verbist, 2013). This confirms that aspects of redistribution, such as the ways of targeting and the demographic structure of the country and their interactions, are important determinants of child poverty. This demonstrates that more research is needed to analyse the crucial effect of national circumstances in relation to child poverty. We recommend complementing the comparative analysis of varied policy environments with an in-depth analysis of particular national transfer systems and socio-demographic structures. Therefore, our conclusions could be considered as a guideline or recommendation for designing policies to reduce child poverty, although sufficient leeway for action should be left for countries regarding the ways and means to achieve these outcomes. 
Finally, our results also reveal some insights related to labour market performance and its close link with the fact of living in poverty. The trickle-down effect from growth and jobs is frequently assumed as the main strategy against poverty, based essentially on boosting labour market participation. However, our findings suggest that a high employment rate is clearly an insufficient condition for ensuring low poverty among the working-age population. Despite the fact that people may be working, in a context of low-paid and precarious jobs, they could have a low standard of living and thus may find themselves and their children below the poverty threshold.

\section{Acknowledgements}

This work was supported by the Government of Spain [grant ECO2015-63734-P (MINECO/FEDER)] and the Spanish Institute for Fiscal Studies [grant 2013-2014]. We also thank three anonymous referees for their useful comments.

\section{Notes}

1 To avoid methodological problems arising from the fact that children living in the same household are not statistically independent observations, we switch from the individual to the household level for the regression analyses.

2 Disposable household income is defined as the sum, for all household members, of gross personal income components plus gross income components at the household level minus regular taxes on wealth and income, social insurance contributions and regular interhousehold transfers paid. Income data correspond to the year prior to the survey for all countries except the UK and Ireland.

3 A value of 1 is assigned to the first adult in the household, 0.5 to each remaining adult and 0.3 to each member younger than 14 .

4 Social transfers cover unemployment benefits, pensions, sickness benefits, disability benefits, education-related allowances, family- or child-related allowances, housing allowances and other social assistance benefits not classified elsewhere. They do not capture the impact of the tax system. We control for the rate of employment in the country to overcome the possible effect of the business cycle on the amount of social transfers.

5 The definitions of some concepts are included in the Appendix.

6 Family/children benefits provided through the fiscal system are not taken into account in the data.

7 Regarding the exchangeability assumption required when treating cluster effects as random, we can assume it is satisfied as we include country-specific covariates (Rabe-Hesketh and Skrondal, 2012: 96).

8 According to Bryan and Jenkins (2015), a minimum of 30 countries is necessary for nonlinear multilevel models in order to obtain reliable results in relation to the contribution of the country effect. We fulfil this requirement.

9 We have tested the convenience of using a multilevel model that captures the country effects on child poverty through likelihood ratio tests for all models.

10 This non-significant effect is net of other characteristics. In sensitivity analyses, we estimated a reduced form model and found that the odds of being poor were significantly greater for children living with parents with bad or very bad health. Nonetheless, perhaps unsurprisingly, higher poverty among those suffering from health problems can be 
accounted for by other variables introduced in the model, such as labour status or age of parents.

11 We have analysed the effect of pro-child and pro-poor targeting separately and conclude that when only pro-child targeting is introduced, the remaining variation in the risk of child poverty between countries is lower than when only pro-poor targeting is introduced. Therefore, pro-child targeting not only contributes more to the reduction of child poverty risk, but also contributes more to the reduction in the variation in the risk of child poverty between countries.

12 We can state that there is no correspondence between the greater effect of pro-child targeting and the size of pro-child compared to pro-poor targeting. Results available from the authors upon request.

\section{Supplementary material}

To view supplementary material for this article, please visit https://doi.org/ 10.1017/Soo47279418000090

\section{References}

Atkinson, A. B. (1998), Poverty in Europe, Jrjo Jahnsson Lectures: Wiley.

Atkinson, B. A. and Marlier, E. (2010), 'Income and living conditions in Europe', Luxembourg: Eurostat.

Bäckman, O. (2009), 'Institutions, structures and poverty - A comparative study of 16 countries, 1980-2000', European Sociological Review, 25, 2, 251-264.

Bäckman, O. and Ferrarini, T. (2010), 'Combating child poverty? A multilevel assessment of family policy institutions and child poverty in 21 old and new welfare states', Journal of Social Policy 39, 2, 275-296.

Besley, T. (1990), 'Means testing versus universal provision in poverty alleviation programmes', Economica 57, 119-129.

Bradshaw, J. (2012), 'The case for family benefits', Children Youth Services Review, 34, 3, 590-596. Bradshaw, J. and Finch, N. (2003), 'Overlaps in dimensions of poverty', Journal of Social Policy, $32,4,513-525$.

Brady, D. (2006), 'Structural theory and relative poverty in rich Western democracies, 19692000', Research in Social Stratification and Mobility, 24, 2, 153-175.

Brady, D., Fullerton, A. and Moren Cross, J. (2009), 'Putting poverty in political context: A multi-level analysis of adults poverty across 18 affluent democracies', Social Forces, 88, 1, 271-299.

Bryan, M. L. and Jenkins, S. P. (2015), 'Multilevel modelling of country effects: a cautionary tale', European Sociological Review 32, 1, 3-22.

Burrows, R. (2003), Poverty and home ownership in contemporary Britain, Bristol: The Policy Press.

Chen, W. H. and Corak, M. (2008), 'Child poverty and changes in child poverty', Demography, $45,3,537-553$.

Chzhen, Y. (2016), 'Unemployment, social protection spending and child poverty in the European Union during the Great Recession', Journal of European Social Policy, 27, 2, 123-137.

Chzhen, Y. and Bradshaw, J. (2012), 'Lone parents, poverty, and policy in the European Union', Journal of European Social Policy, 22, 5, 487-506.

Corak, M. (2006), 'Do poor children become poor adults? Lessons for public policy from a cross country comparison of generational earnings mobility', Research on Economic Inequality, 13, 143-188. 
Devereux, S., Masset, E., Sabates-Wheeler, R., Samson, M., Rivas, A. M. and te Lintelo, D. (2017), 'The targeting effectiveness of social transfers?, Journal of Development Effectiveness, 9, 2, $162-211$.

Diris, R., Vandenbroucke, F. and Verbist, G. (2017), 'The impact of pensions, transfers and taxes on child poverty in Europe: the role of size, pro-poorness and child orientation', Socio-Economic Review, 15, 1, 1-31.

Duflo, E. (2000), 'Child Health and Household Resources in South Africa', American Economic Review, 90, 393-398.

Engster, D. (2012), 'Child poverty and family policies across eighteen wealthy Western democracies', Journal of Children and Poverty, 18, 2, 121-139.

Eurostat (2013), Eurostat regional yearbook 2013, Luxembourg: Eurostat.

Eurostat, European Commission Eurostat database: Available from http://ec.europa.eu/ eurostat/data/database [ accessed 11.04.2017].

EU-SILC LONGITUDINAL UDB (2012) - version 3 of August 2015. Brussels: Eurostat.

Ferrarini, T. (2006), Families, states and labour markets: Institutions, causes and consequences of family policy in post-war welfare states, Cheltenham: Edward Elgar Publishing.

Gornick, J. C. and Jäntti, M. (2012), 'Child poverty in cross-national perspective: Lessons from the Luxembourg Income Study', Children and Youth Services Review, 34, 3, 558-568.

Hamoudi, A. and Thomas, D. (2005), 'Pension Income and the Well-being of Children and Grandchildren: New Evidence from South Africa', California Center for Population Research, 043-05.

Kangas, O. and Palme, J. (2000), 'Does social policy matter? Poverty cycles in OECD countries', International Journal of Health Services, 30, 2, 335-352.

Marx, I., Vanhille, J. and Verbist, G. (2012), 'Combating in-work poverty in continental Europe: An investigation using Belgian case', Journal of Social Policy, 41, 1, 19-41.

Marx, I., Nolan, B. and Olivera, J. (2015) 'The Welfare State and Anti-Poverty Policy in Rich Countries', in A. B. Atkinson and F. Bourguignon (eds.), Handbook of Income Distribution ( Chapter 23). Amsterdam: North Holland.

Marx, I., Salanauskaite, L. and Verbist, G. (2016), 'For the Poor, but Not Only the Poor: On Optimal Pro-Poorness in Redistributive Policies', Social Forces, 95, 1, 1-24.

Matsaganis, M., O’Donoghue, C., Levy, H., Coromaldi, M., Mercader-Prats, M., Rodrigues, C. F. and Tsakloglou, P. (2006), 'Reforming family transfers in southern Europe: is there a role for universal child benefits?', Social Policy and Society, 5, 2, 189-197.

Misra, J., Budig, M. and Moller, S. (2007), 'Reconciliation Policies and the Effects of Motherhood on Employment, Earnings, and Poverty', Journal of Comparative Policy Analysis, 9, 2, 135155 .

Notten, G. and Gassmann, F. (2008), 'Size matters: targeting efficiency and poverty reduction effects of means-tested and universal child benefits in Russia', Journal European Social Policy, 18,3, 260-274.

Rabe-Hesketh, S. and Skrondal, A. (2012), Multilevel and longitudinal modelling using Stata, in Stata Press books. Vol I: Continuous Responses, 3rd edition, College Station, TX: Stata Press.

Salanauskaite, L. and Verbist, G. (2013), 'Is the Neighbour's Grass Greener? Comparing Family Support in Lithuania and Four Other New Member States', Journal of European Social Policy, 23, 315-331.

Scott, K. (2008), 'Growing up in North America: The economic well-being of children in Canada, the United States, and Mexico', Working paper 482, Luxembourg: Luxembourg Income Study.

Skinner, C., Meyer, D., Cook, K. and Fletcher, M. (2017), 'Child maitenance and social security interactions: the poverty reduction effects in model lone parent families across four countries', Journal of Social Policy, 46, 3, 495-516.

Social Protection Committee (2008), 'Child Poverty and Well-Being in the EU: Current status and way forward', Luxembourg: Office for Official Publications of the European Communities. 
Strelitz, J. and Lister, R. (2008), 'Why money matters: Family income, poverty and children's lives'. London: Save the Children.

TÁRKI (2010), 'Child Poverty and Child Well-being in the European Union'. Budapest: TÁRKI Social Research Institute.

TÁRKI (2011), 'Child well-being in the European Union: Better monitoring instruments for better policies'. Budapest: TÁRKI Social Research Institute.

Van Lancker, W. and Van Mechelen, N. (2015), 'Universalism under siege? Exploring the association between targeting, child benefits and child poverty across 26 countries', Social Science Research, 50, 60-75.

Van Oorschot, W. (2002), 'Targeting Welfare: on the Functions and Dysfunctions of MeansTesting in Social Policy' in P. Townsend and D. Gordon (eds) World Poverty: New Policies to Defeat an Old Enemy, Bristol: The Policy Press.

Verbist, G. and Van Lancker, W. (2016), 'Horizontal and Vertical Equity Objectives of Child Benefit Systems: An Empirical Assessment for European Countries' Social Indicators Research, 128, 1299-1318.

Whiteford, P. and Adema, W. (2007), 'What works best in reducing child poverty: A benefit or work strategy?', OECD Social, Employment and Migration Working Papers 51. Paris: OECD Publishing. 